\title{
Impelementasi Perda Pemberantasan Pelacuran di Kabupaten Lamongan
}

\author{
Slamet Sugianto \\ \begin{tabular}{l|l} 
sugi1984@yahoo.co.id & $\begin{array}{l}\text { PondokPesantren Sunan Kalijogo } \\
\text { Simo Kalangan 172 } \\
\text { Surabaya, Indonesia }\end{array}$
\end{tabular}
}

\begin{abstract}
Prostitution evolves along with the progress of civilization, although the fact that prostitution has certainly harmed people's lives. In legal terms, the problem of prostitution in Indonesia has not been fully regulated in the Criminal Code. To fill this legal vacuum, the local government of Lamongan regency issued regulation number 10 of 2004 which essentially regulates the prohibition of prostitution, adultery, or indecent acts. The article is the result of field research in Lamongan District on the Implementation of Perda No. 10 of 2004 concerning the Eradication of Prostitution in Lamongan District. At the end of this article, the conclusion is that the implementation of regulation No. 10 of 2004 concerning the prohibition of prostitution turned out to be less effective. Also, the media of resolving prostitution conflict can be completed through the court whereas the sanctions can be given in the form of a one-month prison sentence. Besides, the enforcement can also be done directly by Satpol PP (PPNS investigators) who work together with social services by assisting prostitutes affected by arrests.
\end{abstract}

Keywords: elimination of Prostitution, Local Government Regulation.

\begin{abstract}
Abstrak: Palacuran tumbuh berkembang selajur dengan perkembangan peradaban. Padahal pelacuran secara pasti telah menimbulkan dampak buruk terhadap kehidupan masyarakat. Secara yuridis, masalah pelacuran/prostitusi di Indonesia belum secara keseluruhan diatur dalam KUHP. Oleh karena itu, guna mengisi kekosongan hukum ini, Pemerintah daerah kabupaten Lamongan mengeluarkan perda nomer 10 tahun 2004 yang pada essensinya mengatur larangan untuk melacurkan diri atau bermaksud untuk mengajak melakukan zina atau perbuatan cabul. Artikel ini merupakan hasil dari penelitian lapangan di Kabupaten Lamongan tentang Implementasi Perda No. 10 Tahun 2004 tentang Pemberantasan Pelacuran di Kabupaten Lamongan. Di akhir dari artikel ini dipaparkan
\end{abstract}


kesimpulan, bahwa pelaksanaan perda No. 10 tahun 2004 tentang larangan pelacuran ternyata kurang efektif. Juga, proses penyelesaian pelacuran bisa diselesaikan melalui jalur pengadilan. Selain itu, juga bisa diberikan sanksi berupa hukuman percobaan kurungan satu bulan. Di samping itu, dalam penegakannya juga bisa dilakukan langsung oleh Satpol PP (penyidik PPNS) yang bekerja sama dengan dinas sosial dengan memberikan binaan kepada pelacur yang terkena razia.

Kata kunci: Pemberantasan pelancuran dan Perda Kota Lamongan

\section{Pendahuluan}

Palacuran tumbuh berkembang selajur dengan perkembangan peradaban. Ia ada, karena adanya masyarakat. ${ }^{1}$ Sampai detik ini tak seorang pun yang tahu, sejak kapan Wanita Tuna Susila (WTS) ${ }^{2}$ tersebut muncul. Sehingga tak salah jika dikatakan bahwa berbicara masalah pelacuran sama saja dengan membuka masalah paling tua di bumi ini. Masalahnya memang lama tetapi selalu terasa baru untuk tetap dibahas dan dibicarakan. ${ }^{3}$

Namun, tidak di ketahui, bukan berarti menyurutkan minat berbagai lapisan masyarakat untuk membicarakan, baik secara serius atau tidak, pasalnya bentuk Wanita Tuna Susila tertua di dunia ini, sudah ditemukan di negara-negara kuno seperti India dan Babilonia. ${ }^{4}$

Seperti umumnya sebuah fenomena sosial kemunculan Wanita Tuna Susila senantiasa menimbulkan

1 Di Ajeng Laily H, "Penanggulangan Prostitusi Perspektif Hadist," Jurnal Lentera XVIII, no. 2 (2016): 44.

2 Menurut Koentjoro, wanita tuna susila (WTS) merupakan istilah sabagai perempuan yang tidak menuruti aturan susila yang berlaku di masyarakat dan dianggap tidak memiliki adap dan sopan santu dalam berhubungan seks. Sedangkan gigolo dijelaskan secara singkat yang dipahami sebagai laki-laki bayaran yang dipelihara atau disewa oleh seorang perempuan sebagai kekasih atau pasangan seksual. Lihat: Koentjoro, On the Spot: Tutur Dari Sarang Pelacur (Yogyakarta: Tinta, 2004), 27.

3 Irmayani, "Pembentukan Perilaku Pelacuran Berlatar Tradisi di Kabupaten Pati dan Jepara, Jawa Tengah," Jurnal Penelitian dan Pengembangan Usaha Kesejahteraan Sosial 11, no. 1 (2006): 25.

4 Mia Amalia, "Analisis terhadap Tindak Pidana Prostitusi Dihubungkan dengan Etika Moral Serta Upaya Penanggulangan di Kawasan Cisarua Kampung Arab," Jurnal Mimbar Justitia II, no. 2 (Juli 2016): 862. 
pro dan kontra dalam sebuah masyarakat tertentu. Sebuah daerah yang terdapat di dalamnya sebuah lokalisasi akan berdampak besar terhadap kehidupan masyarakat di sekitarnya. Tidak jarang akibat dan eksistensi dari sebuah lokalisasi banyak menimbulkan persoalan dari sub lingkungan yang lebih kecil, khususnya lingkungan keluarga. Tidak sedikit terjadi ketidak harmonisan dalam rumah tangga, maraknya pencurian motor (curanmor), banyaknya perkelahian, ${ }^{5}$ yang semua itu sangat meresahkan masyarakat setempat yang dipicu oleh adanya praktek Wanita Tuna Susila.

Munculnya pelacuran atau prostitusi merupakan suatu bentuk penyakit sosial masyarakat yang harus dihentikan penyebarannya, karena merupakan suatu bentuk perbuatan yang terkutuk dan bertentangan dengan kepribadian bangsa Indonesia yang berfalsafah Pancasila. Apabila peraturan sudah menyeret anak gadis atau remaja yang merupakan tendensi adanya krisis moral harus segera diatasi, karena mereka merupakan generasi penerus pejuang bangsa Indonesia. Keberadaan pelacuran sebagai suatu profesi sampai dengan hari ini terus menggerogoti didalam kehidupan sosial masyarakat. Pelacuran sudah anggap sebagai penyebab menjalarnya penyakit kelamin, bahkan penyakit yang sampai hari ini belum dapat ditemukan obat dan penangkalnya, yakni AIDS. ${ }^{6}$

Di sisi lain, masalah seksual (persetubuhan) Allah SWT., telah menetapkan tata cara melakukannya dengan baik dan benar, pada tempatnya, yaitu kepada seorang isteri-isteri dan suami-suami yang sah, yang dihalalkan dengan media "Pernikahan".7 Oleh karena itu, Allah SWT. melarang hamba-Nya melakukan seks bebas (free seks) atau

5 Laily H, "Penanggulangan Prostitusi Perspektif Hadist," 44.

6 Hartono, "Advokasi Terhadap Pelacuran Anak di Lokalisasi Dolly Surabaya," Al-Daulah: Jurnal Hukum dan Perundangan Islam 3, no. 1 (April 2013): 97.

7 Muhammad Ramli, "Muhammad Ramli. 'Penerapan Peraturan Daerah No. 18 Tahun 2004 Tentang Larangan Pelacuran di Kabupaten Pamekasan'. AlJinâyah: Jurnal Hukum Pidana Islam, Vol. 1, No. 2, Desember 2015," Al-Jinâyah: Jurnal Hukum Pidana Islam 1, no. 2 (Desember 2015): 375. 
perzinaan, karena yang demikian itu adalah termasuk perbuatan keji dan dosa besar, sebagaimana dalam QS. alIsra: 32, yang artinya: "Dan janganlah kamu mendekati zina, sesugguhnya zina itu adalah suatu perbuatan yang keji. Dan suatu jalan yang buruk."8

Di samping hukuman fisik tersebut, hukuman moral atau sosial juga diberikan bagi mereka yaitu berupa diumumkan aibnya, diasingkan (taghrib), tidak boleh dinikahi dan ditolak persaksianya. Hukuman ini sebenarnya lebih bersifat prevetif (pencegahan) dan pelajaran berharga bagi orang lain. ${ }^{9}$

Masalah pelacuran/prostitusi di Indonesia belum secara keseluruhan diatur dalam KUHP. Perbuatan zina yang memungkinkan untuk dihukum adalah perbuatan zina yang dilakukan oleh laki-laki maupun wanita yang telah menikah, hal itu pun harus ada pengaduan dari masing-masing pihak, karena merasa namanya tecemar. Oleh karena itu, apabila pasangan dari masing-masing pihak tidak merasa dirugikan dan bersikap diam atas perbuatan yang dilakukan oleh pasangannya, maka hukuman tidak dapat diterapkan kepada orang yang telah melakukan perbuatan zina tersebut. Hal ini dijelaskan dalam KUHP pasal 284. ${ }^{10}$

Sedangkan pasal 296 KUHP hanya melarang mereka yang mempunyai profesi sebagai penyedia sarana (germo) dan mereka yang mempunyai profesi mencari wanita untuk dijadikan pelacur serta para mucikari atau pelindung pelacur. Dalam KUHP tidak ada larangan bagi pekerja seks komersial untuk melacurkan diri atau melakukan transaksi seksual. ${ }^{11}$

8 Departemen Agama Republik Indonesia, Al-Qur'an dan Tarjamah (Surabaya: Al-Hidayah, 2002), 544.

9 Nasrullah Khumaerah, "Patologi Sosial Pekerja Seks Komersial (PSK) Persfektif Al-Qur'an," Jurnal Al-Khitabah III, no. 1 (Juni 2017): 68.

10 Nur Sa'ada, "Tinjauan KUHP dan Fiqh Jināyah terhadap Zina dan Turunannya dalam Qānūn Aceh Tahun 2009 tentang Hukum Jinayat," Jurnal AlQ⿳亠̄⿲丿丨 19 , no. 1 (Juni 2016): 92.

11 Adami Chazawi, Tindak Pidana Mengenai Kesopanan (Jakarta: Raja Grafindo Persada, 2007), 57. 
Oleh karena tidak adanya larangan terhadap pekerja seks komersil untuk melacurkan diri dalam KUHP. Maka guna mengisi kekosongan hukum ini, Pemerintah Daerah Kabupaten Lamongan mengeluarkan Perda No. 10 tahun 2004. Yang pada essensinya mengatur larangan untuk melacurkan diri atau bermaksud untuk mengajak melakukan zina atau perbuatan cabul sebagaimana tercantum dalam Peraturan Daerah No. 10 Tahun 2004 tentang pemberantasan Pelacuran. ${ }^{12}$

Dengan demikian: "Barang siapa yang melanggar pasal 2 pasal 4 ayat 1 dan 2, pasal 6 dan pasal 7 tersebut, akan dikenakan sanksi, Pasal 11 ayat 1 dan 2 berlaku untuk semua tanpa kecuali. Maka bagi para pelanggar peraturan ini berlaku pidana kurungan paling lama 3 (tiga) bulan atau denda paling banyak Rp 50.000.000,- (lima puluh juta rupiah)." Dan, "Apabila dalam kurun waktu tidak lebih dari satu tahun sejak putusan hukum ditetapkan, dia melakukan pelanggaran lagi, maka hukumannya dinaikkan 2 kali."13

Sekalipun KUHP dan peraturan daerah di kabupaten Lamongan tidak mengatur tentang bolehnya pelacuran atau prostitusi, namun pemerintah tampak memperhatikan keberadaannya. Karena sebelum dikeluarkanya Perda larangan ini, prostitusi di Lamongan tidak dilarang keberadaanya. Namun dengan adanya tempat-tempat pelacuran tersebut membuat Kota Lamongan tercemar dan tak indah, sehingga pemerintah kabupaten Lamongan mengeluarkan perda nomer 10 tahun 2004 tentang Pemberantasan Pelacuran. ${ }^{14}$

12 "Peraturan Daerah Kabupaten Lamongan Nomer 10 Tahun 2004 tentang Pemberantasan Pelacuran," 2004, 1.

13 Pada dasarnya, selain KUHP Ketentuan lain yang dapat digunakan dalam menjerat praktik prostitusi adalah Undang-Undang Nomor 21 Tahun 2007 tentang Pemberantasan Tindak Pidana Perdagangan Orang. Lihat: Chazawi, Tindak Pidana Mengenai Kesopanan, 58.

14 Di sini terlihat bahwa tujuan pembuat undang-undang memberlakukan hukum pidana adalah sebagai (1) deterrence (pencegahan), yaitu untuk mencegah agar orang tidak melakukan kejahatan, dan juga (2) rehabilitation, yaitu untuk mereformasi pelaku dan mengubah dia menjadi anggota yang taat hukum dan masyarakat yang produktif. Lihat: Nafi' Mubarok, 'Tujuan 
Akan tetapi apakah dengan dikeluarkannya Perda Nomor 10 tahun 2004 dalam pemberantasan pelacuran, khususnya di kabupaten Lamongan, dapat mengurangi kegiatan pelacuran dan juga tempat-tempat pelacuran yang akhir-akhir ini semakin merajalela. ${ }^{15}$

\section{Metode Penelitian}

Penelitian ini merupakan penelitian lapangan, dengan fokus data yang dibutuhkan berupa:

1. Pelacur atau prostitusi dan permasalahannya.

2. Cara-cara untuk mengatasi pelacuran berdasarkan perda nomer 10 tahun 2004 tentang pemberantasan pelacuran.

3. Efektifitas pemberlakuan perda nomer 10 tahun 2004 di kabupaten Lamongan.

Untuk memperolehnya maka didapatkan sumber data primer dengan cara meminta keterangan maupun penjelasan dari pemerintah daerah tingkat II Lamongan, serta instansi Pengadilan Negeri Lamongan dan instansi lain. Sedangkan untuk memperoleh data sekunder, yang merupakan data pendukung berupa hal-hal yang berkaitan dengan pelacuran dan pemberantasanya maka dengan penelusuran pustaka.

Untuk memperoleh data yang diperlukan dalam penelitian ini, digunakan cara:

1. Teknik wawancara atau interview, dengan mengadakan wawancara atau tanya jawab secara langsung dengan Responden dan Hakim serta Panitera Pengadilan Negeri,

Pemidanaan dalam Hukum Pidana Nasional dan Fiqh Jinayah," Jurnal Al-Qanun 21, no. 2 (Desember 2015): 302-3.

15 Selain Kabupaten Lamongan juga terdapat Kabupaten Pamekasan yang mengeluarkan Perda larang pelacuran. Dengan Perda No. 18 Tahun 2004 tentang Larangan Pelacuran, yang diberlakukan bagi seluruh masyarakat Pamekasan tanpa terkecuali, maka secara implementatif, Pemkab Pamekasan melakukan pengawasan dan penyidikan secara intansional untuk mencari, mengumpulkan, dan meneliti laporan berkenaan dengan tindak pidana pelacuran tersebut. Lihat: Ramli, "Muhammad Ramli. 'Penerapan Peraturan Daerah No. 18 Tahun 2004 Tentang Larangan Pelacuran di Kabupaten Pamekasan'. Al-Jinâyah: Jurnal Hukum Pidana Islam, Vol. 1, No. 2, Desember 2015," 396. 
Pemerintah daerah kabupaten Lamongan dan Instansi lain yang terkait.

2. Teknik observasi, dengan melakukan pengamatan dan pencatatan guna mengetahuai bagaimana efektifitas pemberlakukan perda nomer 10 tahun 2004 dalam pemberantasan pelacuran di kabupaten Lamongan tersebut.

3. Teknik dokumentasi, dengan menggali berkas putusan Pengadilan Negeri Lamongan dalam perkara pelanggaran terhadap perda nomer 10 tahun 2004 .

Selanjutnya, setalah data-data terkumpul, maka untuk menganalisa data tersebut digunakan metode deskriptif ${ }^{16}$ dan metode deduktif. ${ }^{17}$

\section{Pelacuran dan Cara Mengatasinya Definisi Pelacur}

Term pelacuran dan devinisinya dalam kamus bahasa Indonesia diuraikan sebagai berikut: (1) lacur, yang berarti: malang, celaka, gagal, sial, tidak jadi; (2) melacur, yang berarti: berbuat lacur, menjual diri, (sebagai tuna susila/pelacur); (3) pelacur, yang berarti: perempuan yang melacur, sundel, wanita tuna susila; dan (4) pelacuran, yang berarti: perihal menjual diri sebagai pelacur/penyundel. ${ }^{18}$

Menurut Mia Amalia, bahwa pelacuran atau prostitusi adalah penjualan jasa seksual dengan uang sebagai imbalan atau upah. Seseorang yang menjual jasa seksual disebut pelacur, yang kini sering disebut dengan istilah pekerja seks komersial (PSK). Dalam pengertian yang lebih luas,

16 Yaitu upaya menyajikan data dan menyusunnya dengan cara menguraikan data tersebut secara sistematis dan kronologis, sehingga membentuk konfigurasi masalah yang diteliti, mudah dipahami. Lihat: E. Zaenal Arifin, Dasar-dasar Penulisan Karangan Ilmiah (Jakarta: Gramedia, 2003), 55.

17 Metode deduktif merupakan pola pengolahan data yang bertitik tolak dari hal-hal yang bersifat umum, kemudian ditarik kesimpulan yang bersifat khusus. Metode ini digunakan untuk menganalisis data tentang pelacuran dan bagaimana cara mengatasinya yang berangkat dari teori-teori/dalil-dalil, dan pendapat pakar yang bersifat umum kemudian ditarik kesimpulan yang bersifat khusus mengenai pemberantasan pelacuran dan tempat-tempatnya.

18 Burhani MS dan Hasbi Laurens, Kamus Ilmia Populer (Jombang: Lintas Media, 2009), 388. 
seseorang yang menjual jasanya untuk hal yang dianggap tak berharga juga disebut melacurkan dirinya. ${ }^{19}$

Van Amstel menyatakan bahwa prostitusi adalah penyerahan diri wanita kepada laki-laki dengan imbalan pembayaran. $^{20}$ Sedangkan Koentjoro menjelaskan bahwa pelacuran atau prostitusi merupakan suatu bentuk transaksi bisnis yang disepakati oleh pihak yang terlibat sebagai suatu yang bersifat jangka pendek yang memungkinkan satu orang atau lebih mendapatkan kepuasan seks dengan metode yang beraneka ragam. ${ }^{21}$

Selanjutnya Kartini Kartono mendefinisikan prostitusi atau pelacuran sebagai berikut:

1. Prostitusi adalah bentuk penyimpangan sosial, dengan pola-pola organisasi Impuls / doronggan seks yang tidak wajar dan tidak terintegrasi, dalam bentuk pelampiasanpelampiasan nafsu seks tanpa kendali dengan banyak orang, disertai dengan eksploitasi dan komersialisasi seks.

2. Pelacuran adalah merupakan periistiwa penjualan diri (persundelan) dengan jalan menjual belikan badan, kehormatan dan keperibadian kepada banyak orang untuk memuaskan nafsu-nafsu seks, dengan imbalan pembayaran.

3. Pelacur adalah perbuatan perempuan atau laki-laki yang menyerahkan badanya untuk berbuat cabul secara seksual dengan mendapatkan upah. ${ }^{22}$

Sedangkan menurut Peraturan Daerah No. 10 Tahun 2004 tentang Pemberantasan Pelacuran, bahwa "pelacuran adalah siapapun laki-laki maupun perempuan yang

19 Amalia, "Analisis terhadap Tindak Pidana Prostitusi Dihubungkan dengan Etika Moral Serta Upaya Penanggulangan di Kawasan Cisarua Kampung Arab," 871.

20 Definisi di atas mengemukakan adanya unsur-unsur ekonomis, dan penyerahan diri wanita yang dilakukan secara berulang-ulang atau terus menerus dengan banyak laki-laki. Lihat: Kartini Kartono, Patologi Sosial, Jilid 1 (Jakarta: Raja Grafindo Persada, 2005), 214.

${ }^{21}$ Koentjoro, On the Spot: Tutur Dari Sarang Pelacur, 30.

22 Kartono, Patologi Sosial, 216. 
menyediakan diri pada umum untuk melakukan zina dan/atau perbuatan cabul". ${ }^{23}$

Dengan danya unsur komersialisasi dan bertransaksi seks atau perdagangan tukar menukar seks denggan benda bernilai maka pelacur merupakan "profesi" kehidupan manusia. $^{24}$

Dari paparan definisi pelacur dan pelacuran di atas dapat diketahui bahwa pelacur adalah orang (laki-laki atau perempuan) yang menyediakan diri untuk berbuat cabul atau asusila atau zina dengan orang lain dengan imbalan sebagai upah atau jasa.

\section{Faktor-faktor yang melatar belakangi terjadinya prostitusi}

Dengan berlangsungnya perubahan-perubahan sosial yang serba cepat, mengakibatkan ketidak mampuan banyak individu untuk menyesuaikan diri, sehingga menggakibatkan timbulnya disharmonisasi dalam masyarakat dan pada diri sendiri. Peristiwa-peristiwa tersebut di atas memudahkan individu menggunakan polapola responsi/reaksi yang konvensional atau menyimpang dari pola-pola umum yang berlaku. ${ }^{25}$

Kartini Kartono menyatakan bahwa penyebab timbulnya pelacuran adalah:

1. Tidak adanya UU yang mengatur tentang pelacuran. Juga tidak ada larangan terhadap orang-orang yang melakukan relasi seks sebelum pernikahan atau pranikah.

2. Adanya dorongan dan keinginan manusia untuk mengeluarkan kebutuhan seks khususnya di luar ikatan pernikahan

3. Komersialisasi dari seks.

23 "Peraturan Daerah Kabupaten Lamongan Nomer 10 Tahun 2004 tentang Pemberantasan Pelacuran," 4.

${ }^{24}$ Reno Bactiar dan Edy Pornomo, Bisnis Prostituís (Yogyakarta: Pinus, 2007), 16.

25 Hartono, "Advokasi Terhadap Pelacuran Anak di Lokalisasi Dolly Surabaya," 98. 
4. Dekadensi moral.

5. Semakin besarnya penghinaan orang terhadap martabat kaum wanita dan harkat manusia.

6. Keberadaan eksploitasi pada zaman ini.

7. Adanya proyek-proyek pembangunan dan pembukaan daerah-daerah pertambangan daya kosentrasi kaum pria. $^{26}$

Sedangkan menurut Irmayani, faktor-faktor yang menyebabkan seorang wanita melacurkan diri antara lain:

1. Tekonan ekonomi.

2. Karena tidak puas dengan posisi yang ada.

3. Karena kebodohon, tidak mempunyai pendidikan atau intelegensi yang baik.

4. Cacat jiwa.

5. Karena tidak puas dengan kehidupan seksualnya atau hiperseksual. ${ }^{27}$

Sedangkan motif yang melatar belakangi timbulnya prostitusi atau pelacuran antara lain: ${ }^{28}$

1. Faktor ekonomi

Jalan pintas mereka tempuh, sehingga lebih mudah untuk kemudahan mencari uang, hal ini merupakan tuntutan hidup.

2. Faktor pendidikan

Daya pikiran yang lemah menyebabkan mereka melacurkan diri tanpa rasa malu.

3. Niat lahir batin

Mereka ini berniat bahwa menjadi pelacur yang merupakan jalan keluar "terbaik" untuk menikmati kemewahan tanpa usaha keras.

4. Faktor persaingan

Kemiskinan, kebodohan dan kurangnya kesempatan kerja di sektor formal membuat mereka bertindak apa saja, termasuk menjadi pelacur.

5. Faktor sakit hati

26 Kartono, Patologi Sosial, 232.

27 Irmayani, "Pembentukan Perilaku Pelacuran Berlatar Tradisi di Kabupaten Pati dan Jepara, Jawa Tengah," 27-28.

${ }^{28}$ Bactiar dan Pornomo, Bisnis Prostituís, 80-85. 
Ini semisal gagalnya perkawinan, perceraian, akibat pemerkosaan, dan lain-lain, membuat mereka menjadi pelacur.

6. Faktor kemalasan

Mereka malas untuk berusaha lebih keras dan berfikir lebih inovatif dan kreatif untuk keluar dari kemiskinan, kemalasan ini diakibatkan oleh faktor psikis dan mental rendah.

Namun yang perlu diingat, bahwa pelacuran merupakan patologi sosial. Sehingga berdasarkan landasan teori patologi sosial, bahwa penyakit masyarakat diawali dari adanya perilaku pribadi yang menyimpang (individi sosiopatik) dengan tingkah laku menyimpang dari normanorma umum itu merupakan produk dari proses diferensiasi, individualisasi, dan sosialisasi. ${ }^{29}$

\section{Dampak-dampak pelacuran atau prostitusi}

Berlangsungnya perubahan-berubahan sosial yang serba cepat dan berkembang yang tidak sama dalam kebudayaan, mengakibatkan ketidak mampuan banyak individu untuk menyesuaikan diri, mengakibatkan timbulnya disharmoni, konflik eksternal dan internal juga disorganisasi dalam masyarakat dan dalam diri pribadi. Peristiwa-peristiwa tersebut memudahkan individu menggunakan pola-pola reaksi yang inkonvensional atau menyimpang dari pola-pola umum yang berlaku dalam hal ini. Ada pola pelacuran, untuk mempertahankan hidup di tengah-tengah hiruk pikuk alam pembangunan khususnya di Indonesia. ${ }^{30}$

Dilihat dari aspek pendidikan, prostitusi merupakan kegiatan yang demoralisasi. Dari aspek kewanitaan, prostitusi merupakan kegiatan merendahkan martabat wanita. Dari aspek ekonomi, prostitusi dalam praktiknya sering terjadi pemerasan tenaga kerja. Dari aspek kesehatan, praktik prostitusi merupakan media yang sangat efektif

${ }^{29}$ Khumaerah, "Patologi Sosial Pekerja Seks Komersial (PSK) Persfektif AlQur'an," 72.

${ }^{30}$ Kartono, Patologi Sosial, 242. 
untuk menularnya penyakit kelamin dan kandungan yang sangat berbahaya. Dari aspek kamtibmas praktik prostitusi dapat menimbulkan kegiatan-kegiatan kriminal. Dari aspek penataan kota, prostitusi dapat menurunkan kualitas dan estetika lingkungan perkotaan. ${ }^{31}$

Menurut Abdul Rusul Abdul Hasan Al- Ghofar akibat yang ditimbulkan oleh wanita tuna susila sebagai berikut:

1. Melimpahnya anak haram di tengah umat manusia, sehingga melenyapkan nilai-nilai keturunan dan kehormatan.

2. Menurunnya jumlah keturunan, karena para wanita pelacur umumnya memakai pil pencegah kehamilan, aborsi dan lain-lian.

3. Tercerai berainya keluarga dan masyarakat yang mengakibatkan kehancuran.

4. Hilangnya rasa kemanusiaan dan tersebarnya kerusakan dan kehancuran ditengah-tengah masyarakat.

5. Meningkatnya kejahatan, dikarenakan hati manusia tidak lagi memiliki kelembutan, wanita tidak memiliki rasa kasih sayang sedikitpun. ${ }^{32}$

Dalam Islam, pelacuran (zina) sangatlah dilarang. Hal ini mengingat bahwa dampak zina yang sangat berbahaya bagi kehidupan manusia, baik dalam konteks tatanan kehidupan individu, keluarga (nasab) maupun masyarakat. ${ }^{33}$

Cara Mengatasi Pelacuran Berdasarkan Perda No. 10 Tahun 2004 Tentang Pemberantasan Pelacuran Penanggulangan secara pereventif

Penangulangan ${ }^{34}$ secara pereventif diharuskan dalam berbagai bentuk: ${ }^{35}$

31 Amalia, "Analisis terhadap Tindak Pidana Prostitusi Dihubungkan dengan Etika Moral Serta Upaya Penanggulangan di Kawasan Cisarua Kampung Arab," 864.

32 Abdur Rasul dan Abdul Hasan Al-Ghafar, Wanita Islam dan Gaya Hidup Modern (Bandung: Pustaka Hiadayah, 1984), 108-11.

33 Khumaerah, "Patologi Sosial Pekerja Seks Komersial (PSK) Persfektif AlQur'an," 68.

${ }^{34}$ Penanggulangan ini diperlukan, karena jika tidak, maka; (1) berakibat meningkatnya kejahatan, baik dari aspek kuantitas maupun kualitas; (2) 
1. Melakukan upaya-upaya pembinaan dan rehabilitasi terhadap pelacur.

2. Mangadakan penyuluhan secara terpadu dengan intansi terkait yang menyangkut keamanan dan ketertiban wilayah, agama dan kesehatan.

3. Melaksanakan kerjasama dengan kabupaten/kota yang memiliki panti rehabilitasi guna kursus ketrampilan sebagai bekal bagi mucikari maupun pelacur.

4. Mengadakan pengendalian dan penertiban terhadap pelacur, hidung belang dan mucikari/penyedia tempat.

5. Melakukan pendataan penertiban administrasi kependudukan.

6. Melakukan pembinaan, pengendalian dan pencegahan terhadap timbulnya pelacuran.

7. Mendata dan melaporkan ke Tim Penertib melalui Tim Pembina dan Penertib tingkat kecamatan, ketika ada kios/warung/rumah dan lain-lain yang di sinyalir digunakan untuk kegiatan pelacuran.

8. Mangadakan pembinan, pengendalian dan pemantauan serta pencegahan terhadap timbulnya pelacuran di desa.

9. Membentuk Pos Komando (piket) pada lokasi-lokasi rawan pelacuran.

10. Mengantisipasi tumbuh dan berkembangnya kegiatan pelacuran secara dini dengan mengadakan pemantauan di wilayah masing-masing.

11. Intensifikasi pemberian pendidikan keagamaan dan kerohanian untuk memperkuat keimanan terhadap nilai-nilai religius dan norma kesusilaan.

12. Pembentukan Badan atau Tim Kordinasi dari semua usaha penanggulangan pelacuran yang dilakukan beberapa instansi. Sekaligus mengikutsertakan potensi

berdampak memunculkan bentuk-bentuk kejahatan baru di luar perhitungan umat manusia, yang bisa saja merupakan derivasi dari "kejahatan konservatif"; dan (3) berdampak pada tidak dapat teridentifikasinya sebuah kejahatan sebagai kejahatan. Lihat: Nafi' Mubarok, Kriminologi dalam Prespektif Islam (Sidoarjo: Dwiputra Pustaka Jaya, 2017), 2-3.

35 “Keputusan Bupati Lamongan No. 188/741/kep/413/2004, Tentang Pembentukan Tim Penertipan dan Pemberantasan Pelacuran di Kabupaten Lamongan," 2004, 2. 
masyarakat untuk membantu melaksanakan kegiatan pencegahan dan penyebaran pelacuran.

13. Penyitaan terhadap buku-buku dan majalah-majalah cabul, gambar-gambar porno, film-film biru dan saranasarana lain yang merangsang nafsu seks.

\section{Penangulangan secara represif}

Penangulangan secara represif adalah usaha yang dimaksudkan sebagai kegiatan untuk menekan (mengurangi) dan usaha menyembuhkan para wanita dari ketunasusilaan. Untuk kemudian membawa mereka ke jalan yang benar. Usaha represif ini antara lain :

1. Melakukan razia di tempat-tempat yang dijadikan praktek pelacuran.

2. Melakukan penangkapan.

3. Melakukan penyidikan oleh Aparat Penyidik Pegawai Negeri Sipil (PPNS)

4. Melakukan persidangan di Pengadilan Negeri Lamongan.

5. Menetapkan hukuman terhadap pelaku yang tertangkap.

6. Melakukan pembinaan ketempat panti rehabilitasi Sosial karya wanita "Ngudi Rahayu" Kediri.

Sanksi Pidana Menurut Peraturan Daerah No. 10 Tahun 2004 Tentang Pemberantasan Pelacuran Di Kabupaten Lamongan.

Pelangaran terhadap pasal-pasal:

1. Pasal 2 ayat 1: "Siapapun yang ada di jalan, didekat atau ditempat-tempat yang kelihatan dari jalan, atau ditempat umum maupun juga, dilarang membujuk atau memikat orang lain dengan perkataan-perkataan, isaratisarat, tanda-tanda atau perbuatan lainya, yang maksudnya mengajak untuk melakukan zina atau perbuatan cabul, dengan secara langsung maupun tidak langsung."

2. Pasal 4 ayat 1 dan 2: 
Ayat 1: "Dalam Daerah kabupaten Lamongan tidak di perkenankan adanya tempat pelacuran dalam segala bentuk dan dalih apapun."

Ayat 2: "Bupati kepala Daerah Kabupaten Lamongan dengan surat keputusanya berhak mengeluarkan perintah penutupan terhadap setiap tempat, apabila berdasarkan pertimbangan atau atas usul salah seorang pejabat atau yang diberi tugas untuk pengusutan sebagai tersebut dalam pasal 10 memperoleh keyakinan, bahwa tempat itu adalah tempat pelacuran."

3. Pasal 5 ayat 2: "Penangung jawab tempat yang dimaksud dalam pasal 4 ayat (2) bertangung jawab secara pribadi atas keamanan/keselamatan atau terhadap salinan surat keputusan penutupan yang telah ditempelkan. Apabila karena sesuatu hal yang disebabkan karena bukan kesalahan penanggug jawab tempat yang bersangkutan terjadi sesuatu dengan salinan surat keputusan tidak lagi berada di tempat yang telah ditentukan, ataupun berubah dari keadaanya semula, sehingga tidak lagi muda di lihat dan tidak lagi muda di baca oleh tiap-tiap orang,maka penanggung jawab tempat itu di dalam waktu dua puluh empat (24) jam bagi yang berdiam di dalam kota kabupaten Lamongan,atau dalam waktu tiga kali dua puluh empat jam(hari minggu dan hari besar tidak dihitung) bagi yang berdiam di luar kota kabupaten Lamongan, harus memberitahukan hal itu kepada Bupati kepala daerah Lamongan dengan di sertai keterangan-keterangan dan alasan-alasan secukupnya."

4. Pasal 6: "Siapapun dilarang mendatangi atau berada sebagai tamu di tempat seperti tersebut dalam ayat (2) pasal 4, setelah diperintahkan penutupanya, dan diumumkan dengan cara sebagai tersebut dalam pasal 5 ayat (1)."

5. Pasal 7: "Penangung jawab tempat-tempat yang telah diperintahkan penutupanya seperti terurai dalam ayat 2 pasal 4 dan diumumkan dengan cara, sebagai termaksud dalam pasal 5 ayat (1) dilarang menerima atau membiarkan kedatangan para tamu di dalamnya." 
6. Pasal 11 ayat 1 dan 2:

Ayat 1: "Pelangaran tarhadap ketentuan-ketentuan dalam pasal 2, pasal 4 ayat 1 , pasal 5 ayat 2, pasal 6 dan pasal 7 diancam pidana kurungan paling lama 3 (tiga) bulan atau denda paling banyak Rp 50.000.000; (lima puluh juta rupiah)."

Ayat 2: "Apabila terjadi pelanggaran ulang (residive) dari perbuatan pidana seperti dimaksud dalam ayat 1 pasal ini, dalam waktu tidak lebih dari satu tahun sejak penghukuman pelanggaran pertama yang tidak dapat diubah lagi, maka hukuman maksimum yang termaksud dalam ayat 1 pasal ini dapat dinaikkan dua kali."

\section{Kendala-kendala dalam Pemberantasan Pelacuran}

Dalam rangka pemberantasan pelacuran dikabupaten lamongan, selama ini sering aparat mengalami kendala dalam melakukan penjaringan terhadap keberadaan PSK diwilayah Lamongan. Hal-hal yang menjadi kendala antara lain:

1. Seringnya para PSK berpindah-pindah tempat sehingga saat aparat melakukan razia para PSK tidak ada ditempat (bersembunyi).

2. Sering bocornya akan adanya berita ketelinga para PSK. Hal ini karena adanya segelintir "oknum" yang membocorkan karena medapatkan keuntungan adanya bisnis prostitusi tersebut.

3. Belum tersedianya tempat untuk membina para PSK di Kabupaten Lamongan sehingga para PSK yang tertangkap dikirim di Panti Rehabilitasi di Kediri.

4. Belum adanya tempat tahanan khusus wanita di Lembaga Pemasyarakatan (LP) Lamongan sehungga hakim dalam memberikan hukuman penjara (kurungan) sangat jarang. Hal ini yang menjadi pertimbangan hakim dalam menjatuhkan hukuman terhadap para pelacur yang tertangkap. ${ }^{36}$

36 Sukiman (Kasi Operasi dan Pengamanan Satpol PP Kabupaten Lamongan) Sukiman, Wawancara, 18 Juni 2007. 


\section{Efektifitas Perda No. 10 Tahun 2004 Tentang Pemberantasan Pelacuran di Kabupaten Lamongan}

Sebagai mana sudah dijelaskan dalam pembahasan sebelumnya. Di atas bahwasanya dampak negatif dari adanya pelacuran/prostitusi terhadap masyarakat. Sangat nampak dan juga peraktek tersebut bertentangan dengan norma agama, norma hukum, norma susila, serta membahayakan tata pergaulan bagi mesyarakat. Karena banyak bahaya yang ditimbulkan olah adanya pelacuran tersebut, maka Pemerintah Daerah Kabupatan Lamongan melarang adanya tempat-tempat prostitusi/pelacuran dengan alasan apapun dan dengan dalih apapun.

Dari 27 kecamatan, ada 10 kecamatan yang memiliki tempat pelacuran di kabupaten Lamongan. Jumlah tempat pelacuran seluruhnya kurang lebih 22 tempat. Dan banyaknya pelacuran di jalanan, maka Pemerintah Daerah Kabupaten Lamongan mengeluarkan Perda No. 10 Tahun 2004 tentag Pemberantasan Pelacuran, sebagai penegas dari Instruksi Bupati Lamongan No.188/741/Kep/413.013/2004 tentang Penutupan Tempat Pelacuran dan Lokalisasi yang ada di Lamongan. Dengan banyaknya dukunganya masyarakat terhadap pemberlakuan peraturan daerah tersebut, maka efektifitas pemberlakuan Perda Pemberantasan Prostitusi ini bisa dikatakan efektif. Hal ini bisa dilihat dari berkurangnya tempat-tempat pelacuran yang ada. Dari 22 menjadi 16, yang berhasil ditutup 6 tempat lokalilsasi.

Hal ini juga dibuktikan dengan seringnya aparat penegak hukum melakukan razia. Juga Hakim memberikan putusan dalam persidangan terhadap pelangaran Perda No. 10 Tahun 2004 ini. Dengan terbuktinya 64 kasus pelanggaran terhadap Perda ini, tercatat semenjak diundangkannya sampai akhir Mei 2006.

Namun kalau kembali kepada persoalan pelacuran yang banyak menimbulkan efek negatif dan ini juga sebagai tindakan mengisi kekosongan hukum yang ada karena di dalam Kitab Undang-undang Hukum Pidana (KUHP). 
Masalah pelacuran tidak ada sanksi yang jelas melainkan dalam KUHP yang diatur hanyalah mereka para mucikari dan penyedia tempat-tempat pelacuran yang ada hukumnya. Akan tetapi bagi pelakunya sendiri tidak diatur. Oleh karena itu, Pemerintah Daerah Kabupaten Lamongan mengeluarkan Peraturan Daerah No 10 Tahun 2004 tentang Pemberantasan pelacuran ini.

Mengenai efektifitas pemberlakuan Perda ini sedikit banyak akan mempunyai pengaruh positif bagi warga Lamongan dan sekitarnya. Dampak positif bagi masyarakat Lamongan itu adalah akan terciptanya kondisi masyarakat yang jauh dari kesenjangan-kesenjangan sosial, dan ketertiban dalam masyarakat akan terjamin. Juga, kejahatan tidak meningkat, dan bagi pekerja seks komersial (PSK) dari luar wilayah kabupaten Lamongan mereka akan takut jika mereka akan praktek di Lamongan.

Ini tak lepas bahwa salah satu tujuan penggunaan hukum pidana adalah bertujuan mencegah dan mengurangi kejahatan, atau hal-hal yang dianggap menyimpang oleh masyarakat. ${ }^{37}$

Untuk mengetahui efektifitas dari pemberlakuan Perda No. 10 tahun 2004 berikut ini hasil wawancara dengan beberapa nara sumber:

1. Menurut Kasi operasi dan pengamanan Bapak Drs. Sukiman beliau menilai bahwa sejak diberlakukannya peraturan daerah No. 10 tahun 2004 tentang pemberantasan pelacuran di Lamongan, dirasa cukup efektif. dikarenakan diberlakukannya perda ini dapat mengurangi keberadaan pelacur di Lamongan, meskipun tidak bisa diberantas secara keseluruhan. Karena penanganan pelacuran memang dirasa sulit. Mereka para pelaku pelacuran sering berpindah-pindah dan menghilang saat dilakukan razia (penjaringan). ${ }^{38}$

2. Menurut Irwan Efendi, SH., hakim di Pengadilan Negeri Lamongan yang pernah menyidangkan perkara

37 Nafi' Mubarok, Suplemen Pengetahuan Hukum Pidana (Surabaya: Fakultas Syariah dan Hukum UIN Sunan Ampel, 2017), 38.

38 Sukiman, Wawancara. 
pelanggaran terhadp Perda No. 10 Tahun 2004 ini. Bahwa dalam pelaksanaannya perda larangan pelacuran di Lamongan di rasa cukup efektif, karena dengan adanya perda larangan prostituís ini hakim punya dasar untuk menjatuhkan hukuman (sanksi) sesuai dengan perda yang berlaku di Lamongan. Hal ini dibuktikan dengan putusan pengadilan yang memberikan sanksi yang menjerakan. ${ }^{39}$

\section{Analisis Terhadap Penerapan Perda No. 10 Tahun 2004 Tentang Pemberantasan Pelacuran Di Kabupaten Lamongan \\ Analisis terhadap cara-cara mengatasi pelacuran}

Pemerintah Daerah Kabupaten Lamongan dalam menangani masalah pelacuran di Lamongan menggunakan dua cara penanggulangan yaitu:

1. Secara preventif

Dalam menangani secara preventif pemerintah daerah kabupaten Lamongan berupaya untuk membina para pelacur agar kejalan yang benar dan meninggalkan kegiatan pelacuran. Pemerintah daerah kabupaten Lamongan dalam menangani pelacuran melibatkan beberapa Instansi, mulai dinas Polisi Pamong Praja, Dinas Sosial, Dinas Kesehatan, Kepolisian dan Pengadilan Negeri Lamongan. Dari Instansi-instansi tersebut pemerintah kabupaten Lamongan berupaya dengan berbagai cara dengan memberikan ketrampilan, memberikan pendidikan keagamaan dan pemantauan kesehatan.

Peran serta masyarakat dan tokoh agama ${ }^{40}$ sangat berpengaruh dalam membantu pelaksanaan peraturan daerah tentang larangan pelacuran di Lamongan. Karena

39 Irwan Efendi, Wawancara, 18 Juni 2007.

40 Hal ini tak lepas bahwa dalam hal fungsi, agama sangat berperan terhadap masyarakat dalam mengatasi persoalan-persoalan yang timbul di masyarakat yang tidak dapat selesaikan secara empiris oleh individuindividu dalam masyarakat dikarenakan adanya keterbatasan kemampuan dan ketidakpastian. Lihat: Mubarok, Kriminologi dalam Prespektif Islam, 10. 
dengan peran serta masyarakat secara langsung para pelacur akan merasa takut jika melakukan praktek di wilayah kabupaten Lamongan. Juga, tidak jarang masyarakat di Lamogan yang kedapatan wilayahnya terdapat tempat pelacuran, warga beserta tokoh masyarakat melakukan pengusiran dan pembongkaran rumah-rumah yang dijadikan praktek pelacuran. Mereka para pelacur diusir dari wilayahnya.

2. Secara represif

Pemerintah daerah kabupaten Lamongan dalam menangani masalah pelacuran jika menggunakan cara represif. Pemerintah mengerahkan aparat penegak hukum khususnya Satuan Polisi Pamong Praja. Aparat ini sering melakukan razia (penjaringan) ketempattempat pelacuran. Aparat dalam melakukan razia sering kejar-kejaran. Karena para pelacur jika mengetahui akan adanya operasi (razia) mereka berhamburan lari untuk bersembunyi. Dan dalam melakukan tindakan razia ini aparat sendiri memang merasa kesal karena sebelum razia di mulai sering berita akan adanya razia itu bocor kepada para pelacur. Hal ini karena adanya kepentingan-kepentingan dari "Segelintir Orang" yang mendapatkan keuntungan dari adanya bisnis pelacuran itu sendiri.

Dalam melakukan penyidikan dan penetapan sanksi menurut peneliti sanksi yang dijatuhkan amat sangat kurang berat. Karena para pelacur yang tertangkap biasanya dikenai Sanksi Denda atau hukuman 1 bulan (percobaan). Hal ini dianggap ringan oleh pelacur, karena hanya dengan membayar mereka bebas dan akan melakukan praktek lagi.

Dalam melakukan pembinaan di panti rehabilitasi seharusnya tidak diberi tawaran mau atau tidak? Sebenarnya hal ini harus dipaksakan karena mereka harus di bina, diberi ketrampilan, dan supaya taubat. Selama ini yang dikirim ke Panti rehabilitasi kelas 1 Jawa Timur di Kediri hanya para pelacur yang mau saja. 
Sedangkan yang tidak mau hannya dikenai sanksi denda atau kurungan.

\section{Analisis Terhadap Efektifitas Pemberlakuan Perda No. 10 Tahun 2004 Tentang Pemberantasan Pelacuran}

Pemerintah Daerah Kabupaten Lamongan dalam menanggulangi masalah pelacuran/prostitusi menggunakan suatu peraturan daerah. Perda ini timbul disebabkan untuk mempertegas dari intruksi Bupati tentang penutupan lokalisasi dan tempat-tempat prostitusi yang sudah ada lebih dahulu. Sedangkan sanksi dalam Pemerintah Daerah Kabupaten Lamongan tercantum pada Pasal 11 Ayat 1 dan 2, yang berbunnyi:

1. Pelanggaran terhadap ketentuan-ketentuan dalam Pasal 2, Pasal 4 Ayat 1, Pasal 5 Ayat 2, Pasal 6 dan Pasal 7, diancam pidana kurungan paling lama 3 Bulan atau denda paling banyak Rp. 50.000.000 (Lima Puluh Juta Rupiah)

2. Jika terjadi pengulangan pelanggaran (residive) sebagaimana dimaksud ayat 2 pasal 11, maka dalam waktu tidak lebih dari satu tahun sejak penghukuman pelanggaran pertama yang tidak dapat di ubah lagi, maka hukuman maksimum juga termaksud dalam ayat 2 pasal ini dapat dinaikkan dua kali.

Dalam hukuman ini sebenarnya memerangi Faktor Psikologi yang mendorong di perbuatnya jarimah zina. ${ }^{41}$ Sebab hal ini sesuai dengan tujuan pokok penjatuhan sanksi atau hukuman dalam Syari'at Islam yaitu pencegahan, pengajaran dan pendidikan sehingga dapat menekan dan mencegah seseorang agar tidak meniru melakukan pelacuran. ${ }^{42}$ Dan juga Islam tidak membolehkan perbuatan

${ }^{41}$ Syariat islam telah menetapkan tiga jenis hukuman untuk jarīmah zinā yaitu: Dera (Jilid), Pengasingan, Rajam. Untuk hukuman dera seratus kali dan pengasingan ditetapkan untuk pelaku zinā yang keduanya ghoir muhshan (Belum menikah). Hukuman rajam bagi pelaku zinā yang keduanya Muhshan (menikah). Lihat: Sa'ada, "Tinjauan KUHP dan Fiqh Jināyah terhadap Zina dan Turunannya dalam Qānūn Aceh Tahun 2009 tentang Hukum Jinayat," 102-3.

42 Mubarok, "Tujuan Pemidanaan dalam Hukum Pidana Nasional dan Fiqh Jinayah," 320. 
apa saja yang memungkinkan membawa terjadinya perzinaan.

Efektifitas pemberlakuannya, pemerintah daerah menunjuk dinas Satuan Polisi Pamong Praja kabupaten Lamongan untuk menjalankan operasi penjaringan (razia) yang dilaksanakan setiap satu minggu sekali dan jika ada laporan dari Masyarakat. Dengan dilakukannya operasi penjaringan (razia) ini maka terbukti bahwa pemerintah daerah khususnya Sat.Pol.PP menjalankan tugasnya sesuai ketentuan-ketentuan dan peraturan daerah yang ada.

Memang ketika berbicara efektifitas, maka bermula bahwa hukum akan menjadi berarti apabila perilaku manusia di pengaruhi oleh hukum dan apabila masyarakat menggunakan hukum menurut perilakunya, sedangkan di lain pihak efektivitas hukum berkaitan erat dengan masalah kepatuhan hukum sebagai norma. ${ }^{43}$

Sebagaimana hasil penelitian penulis bahwa efektifitas pemberlakuan Perda No. 10 Tahun 2004 tentang Pemberantasan Pelacuran dapat dinyatakan kurang efektif. Karena hanya 6 tempat pelacuran di 3 lokalisasi yang di tutup.

Dengan frekuensi penjaringannya (razia) yang sering dilakukan oleh Satuan Polisi Pamong Praja kabupaten Lamongan dan juga penegakan hukum oleh Pengadilan Negeri Lamongan dalam menjatuhkan sanksi masih belum begitu tegas. Hal ini terlihat dengan sudah banyaknya pelanggaran terhadap perda No. 10 tahun 2004 tersebut. Yang mana oleh Hakim dalam memutuskan jarang menjatuhkan hukuman Kurungan(penjara). Melainkan putusan menyatakan dengan denda Uang atau kurungan percobaan 1 bulan, dan rata-rata pelaku dikenakan paling sedikit Rp. 100.000 (seratus ribu rupiah). Padahal dalam pasal 11 disebutkan denda maksimum Rp. 50.000.000 (lima puluh juta rupiah).

43 Sa'ada, "Tinjauan KUHP dan Fiqh Jināyah terhadap Zina dan Turunannya dalam Qānūn Aceh Tahun 2009 tentang Hukum Jinayat," 90. 
Dengan putusan seperti itu maka belum bisa membuat para pelaku (pekerja seks komersial) jera. Karena hasil yang didapat lebih besar dibandingkan dengan sanksi denda sebesar itu. Untuk itu maka jika Pemerintah Daerah Kabupaten Lamongan ingin lebih efektif, maka pelanggar sepatutnya diberi hukuman kurungan agar mereka jera dan bisa insyaf. Padahal salah satu tujuan penggunaan hukum pidana adalah bertujuan mencegah dan mengurangi kejahatan, atau hal-hal yang dianggap menyimpang oleh masyarakat. ${ }^{44}$

Dengan diberlakukannya Peraturan Daerah No. 10 Tahun 2004 tentang Pemberantasan Pelacuran seperti itu, maka para pelaku pelacuran akan jera. Bahkan tidak akan melakukannya lagi atau manjajakan dirinya, dikarenakan hukuman yang diterapkan di kabupaten Lamongan sangat berat. Sehingga para pelaku dari luar daerah kabupaten Lamongan tidak berani lagi untuk melakukan praktek pelacuran di kabupaten Lamongan.

\section{Penutup}

Berdasarkan uraian-uraian pada bab diatas dapat ditarik beberapa kesimpulan :

1. Pemerintah daerah kabupaten Lamongan telah menerbitkan Perda No. 10 tahun 2004 tentang pemberantasan pelacuran dalam perda tersebut Pemerintah kabupaten Lamongan mengerahkan aparatnya yaitu:

a. Satpol PP untuk melakukan razia-razia ketempattempat pelacuran

b. Melakukan pembinaan kepada para pelacur agar tidak melakukan praktek pelacuran

c. Menjatuhkan sanksi kepada para pelacur agar jera

2. Pelaksanaan Perda No. 10 tahun 2004 tentang pemberantasan pelacuran ternyata kurang efektif, karena masih banyak pelaku pelacuran. Dan belum ditutupnya semua tempat-tempat pelacuran yang ada.

44 Mubarok, Suplemen Pengetahuan Hukum Pidana, 38. 
Hal ini terbukti dengan masih adanya tempat-tempat pelacuran di kabupaten Lamongan yang masih tetap beroperasi.

\section{Daftar Pustaka}

Amalia, Mia. "Analisis terhadap Tindak Pidana Prostitusi Dihubungkan dengan Etika Moral Serta Upaya Penanggulangan di Kawasan Cisarua Kampung Arab." Jurnal Mimbar Justitia II, no. 2 (Juli 2016).

Arifin, E. Zaenal. Dasar-dasar Penulisan Karangan Ilmiah. Jakarta: Gramedia, 2003.

Bactiar, Reno, dan Edy Pornomo. Bisnis Prostituís. Yogyakarta: Pinus, 2007.

Burhani MS, dan Hasbi Laurens. Kamus Ilmia Populer. Jombang: Lintas Media, 2009.

Chazawi, Adami. Tindak Pidana Mengenai Kesopanan. Jakarta: Raja Grafindo Persada, 2007.

Departemen Agama Republik Indonesia. Al-Qur'an dan Tarjamah. Surabaya: Al-Hidayah, 2002.

Efendi, Irwan. Wawancara, 18 Juni 2007.

Hartono. "Advokasi Terhadap Pelacuran Anak di Lokalisasi Dolly Surabaya." Al-Daulah: Jurnal Hukum dan Perundangan Islam 3, no. 1 (April 2013).

Irmayani. "Pembentukan Perilaku Pelacuran Berlatar Tradisi di Kabupaten Pati dan Jepara, Jawa Tengah." Jurnal Penelitian dan Pengembangan Usaha Kesejahteraan Sosial 11, no. 1 (2006).

Kartono, Kartini. Patologi Sosial. Jilid 1. Jakarta: Raja Grafindo Persada, 2005.

“Keputusan Bupati Lamongan No. 188/741/kep/413/2004, Tentang Pembentukan Tim Penertipan dan

Pemberantasan Pelacuran di Kabupaten Lamongan," 2004. Khumaerah, Nasrullah. "Patologi Sosial Pekerja Seks Komersial (PSK) Persfektif Al-Qur'an.” Jurnal Al-Khitabah III, no. 1 (Juni 2017).

Koentjoro. On the Spot: Tutur Dari Sarang Pelacur. Yogyakarta: Tinta, 2004.

Laily H, Di Ajeng. "Penanggulangan Prostitusi Perspektif Hadist." Jurnal Lentera XVIII, no. 2 (2016).

Mubarok, Nafi'. Kriminologi dalam Prespektif Islam. Sidoarjo: Dwiputra Pustaka Jaya, 2017. 
- - - Suplemen Pengetahuan Hukum Pidana. Surabaya: Fakultas Syariah dan Hukum UIN Sunan Ampel, 2017.

- - - "Tujuan Pemidanaan dalam Hukum Pidana Nasional dan Fiqh Jinayah." Jurnal Al-Qanun 21, no. 2 (Desember 2015).

"Peraturan Daerah Kabupaten Lamongan Nomer 10 Tahun 2004 tentang Pemberantasan Pelacuran," 2004.

Ramli, Muhammad. "Muhammad Ramli. 'Penerapan Peraturan Daerah No. 18 Tahun 2004 Tentang Larangan Pelacuran di Kabupaten Pamekasan'. Al-Jinâyah: Jurnal Hukum Pidana Islam, Vol. 1, No. 2, Desember 2015." Al-Jinâyah: Jurnal Hukum Pidana Islam 1, no. 2 (Desember 2015).

Rasul, Abdur, dan Abdul Hasan Al-Ghafar. Wanita Islam dan Gaya Hidup Modern. Bandung: Pustaka Hiadayah, 1984.

Sa'ada, Nur. "Tinjauan KUHP dan Fiqh Jināyah terhadap Zina dan Turunannya dalam Qānūn Aceh Tahun 2009 tentang Hukum Jinayat." Jurnal Al-Qānün 19, no. 1 (Juni 2016).

Sukiman, Sukiman (Kasi Operasi dan Pengamanan Satpol PP Kabupaten Lamongan). Wawancara, 18 Juni 2007. 